\title{
Effect of Nutrient and Residue Management Practices on Growth and Yield of Rice in Rice - Maize Cropping System
}

\author{
Mukesh Kumar Pandey ${ }^{1 *}$, Narendra Pandey ${ }^{1}$, Rajendra Lakpale $^{1}$ and Ajay Verma ${ }^{2}$ \\ ${ }^{1}$ Department of Agronomy, College of Agriculture, Raipur, India \\ ${ }^{2}$ Department of Farm Machinery and Power Engineering, FAE, IGKV, Raipur, India \\ Indira Gandhi Krishi Vishwavidyalaya, Raipur- 432012 (Chhattisgarh), India
}

*Corresponding author

\section{A B S T R A C T}

Keywords

Rice - maize cropping system,

Plant height,

Number tillers, Dry

matter accumulation

Article Info

Accepted:

07 November 2019

Available Online:

10 December 2019
Rice - maize cropping system is prominent adapted by the farmers in many parts of the country. Field experiment was conducted for the "effect of nutrient and residue management practices under rice - maize cropping system" with ten treatments during Kharif 2016 and 2017 at Research-Cum-Instructional Farm of Indira Gandhi Krishi Vishwa Vidyalaya, Raipur, Chhattisgarh, India. The results of rice under rice - maize cropping system revealed that of $\mathrm{T}_{5}$ $100 \% \operatorname{RDF}\left(\mathrm{N}_{100} \mathrm{P}_{60}\left(25 \% \mathrm{P}_{2} \mathrm{O}_{5}\right.\right.$ at $\mathrm{RI}$ and $75 \%$ as basal $\left.) \mathrm{K}_{40}\right)+$ Trichoderma produced higher grain yield $\left(56.71 \mathrm{q} \mathrm{ha}^{-1}\right)$ during both the years, which was significantly superior to $\mathrm{T}_{1}$ - F P $\left(\mathrm{N}_{103} \mathrm{P}_{57.5} \mathrm{~K}_{45}\right), \mathrm{T}_{3}-100 \% \mathrm{RDF}\left[\mathrm{N}_{100} \mathrm{P}_{60}(25\right.$ $\% \mathrm{P}_{2} \mathrm{O}_{5}$ at $\mathrm{RI}$ and $75 \%$ as basal) $\left.\mathrm{K}_{40}\right], \mathrm{T}_{4}-100 \%$ RDF $\left(\mathrm{N}_{100} \mathrm{P}_{60} \mathrm{~K}_{40}\right)+$ Trichoderma, and $\mathrm{T}_{9}-75 \% \mathrm{RDF}\left[\mathrm{N}_{75} \mathrm{P}_{45}\left(25 \% \mathrm{P}_{2} \mathrm{O}_{5}\right.\right.$ at $\mathrm{RI}$ and $75 \%$ as basal $)$ $\left.\mathrm{K}_{30}\right]+$ Trichoderma and treatment $\mathrm{T}_{10}$ - control showed the lower performance out of ten treatment. The increase in grain yield was due to significant increase in growth and yield attributing parameter of rice i.e. plant height, number tillers, dry matter accumulation, grain $\left(56.71 \mathrm{q} \mathrm{ha}^{-1}\right)$ and straw yield $(80.08 \mathrm{q}$ $\left.\mathrm{ha}^{-1}\right)$.

\section{Introduction}

Farmers are harvesting handsome yield of rice (about 6.0-8.0 t). Thus, exhaust a sizeable amount of nutrients from the soil and needs proper attention for sustaining productivity and soil health in longer time. The rice-maize cropping system extracts large amounts of mineral nutrients from the soil may accelerate the problem of secondary and micronutrient deficiencies not only because larger amounts are removed, but also because the application of high rates of $\mathrm{N}, \mathrm{P}$ and $\mathrm{K}$ to achieve yield targets (Johnston et al., 2009). However, a proper nutrient management of rice-maize is required with respect to adequate nutrient 
supply, minimize loss and maximize the efficiency use of all the nutrients; the N, P and $\mathrm{K}$ remain the major ones for increased and sustained productivity (Pramanik et al., 2004 and Ilias et al., 2005). The rice - maize system removes large amount of nutrients not only due to high grain production but also due to removal of crop straw from fields. Now days, rice is being harvesting by harvester, which left nearly 5-7 $\mathrm{t} \mathrm{ha}^{-1}$ of rice residue in the field (Krishna et al., 2004) which, needs to be managed for the benefit of next crops. Similarly maize also extract large amount of nutrients and left huge quantity of stover after harvesting final produce. The incorporation of residue in soil system is an important way to add the nutrient in the soil and enhanced soil health, but advantage of added crop residue to cropping system and nutrient sowing and nutrient saving may vary according to soil and climatic condition and need to work out. Nitrogen and phosphorus have been important role in residue decomposition Hua et al., (2013) and Upadhyay et al., (2003). Similarly Trichoderma also helps fasten to decomposition of residue in the system. The benefit of residue incorporation in the soil after harvesting economics yield has been suggested by various workers Balasubramaniam et al., (1991), Prasad et al., (1991) and Mari et al., (2004).

\section{Materials and Methods}

The field experiment was conducted during Kharif 2016 and 2017 at Research Cum Instructional Farm of Indira Gandhi Krishi Vishwa vidyalaya, Raipur, Chhattisgarh, India. The 10treatments comprising with different nutrients ad residue management practices were layout in RBD with three replications. The 10 treatments i.e. $\mathrm{T}_{1}-\mathrm{F} \mathrm{P}$ $\left(\mathrm{N}_{103} \mathrm{P}_{57.5} \mathrm{~K}_{45}\right), \mathrm{T}_{2}-100 \% \operatorname{RDF}\left(\mathrm{N}_{100} \mathrm{P}_{60} \mathrm{~K}_{40}\right)$, $\mathrm{T}_{3}-100 \%$ RDF $\left(\mathrm{N}_{100} \mathrm{P}_{60}\left(25 \% \mathrm{P}_{2} \mathrm{O}_{5}\right.\right.$ at $\mathrm{RI}$ and $75 \%$ as basal) $\left.\mathrm{K}_{40}\right), \mathrm{T}_{4}-100 \% \operatorname{RDF}\left(\mathrm{N}_{100} \mathrm{P}_{60}\right.$ $\left.\mathrm{K}_{40}\right)+$ Trichoderma, $\mathrm{T}_{5}-100 \% \operatorname{RDF}\left(\mathrm{N}_{100} \mathrm{P}_{60}\right.$
(25 \% $\mathrm{P}_{2} \mathrm{O}_{5}$ at $\mathrm{RI}$ and $75 \%$ as basal) $\mathrm{K}_{40}$ ) +Trichoderma, $\mathrm{T}_{6}-75 \% \mathrm{RDF}\left(\mathrm{N}_{75} \mathrm{P}_{45} \mathrm{~K}_{30}\right), \mathrm{T}_{7}$ - $75 \%$ RDF $\left(\mathrm{N}_{75} \mathrm{P}_{45}\left(25 \% \mathrm{P}_{2} \mathrm{O}_{5}\right.\right.$ at $\mathrm{RI}$ and $75 \%$ as basal) $\left.\mathrm{K}_{30}\right), \mathrm{T}_{8}-75 \% \operatorname{RDF}\left(\mathrm{N}_{75} \mathrm{P}_{45} \mathrm{~K}_{30}\right)+$ Trichoderma, $\mathrm{T}_{9}-75 \%$ RDF $\left(\mathrm{N}_{75} \mathrm{P}_{45}(25 \%\right.$ $\mathrm{P}_{2} \mathrm{O}_{5}$ at $\mathrm{RI}$ and $75 \%$ as basal) $\left.\mathrm{K}_{30}\right)+$ Trichoderma and $\mathrm{T}_{10}$ - Control (no fertilizer). During first season of rice crop i.e. Kharif 2016, maize residue @ $5 \mathrm{t} \mathrm{ha}^{-1}$ (ex-situ) was uniformly spread up 25 days before sowing on entire experimental area. While, in subsequence season in situ maize residue was incorporate. The disc harrow was used to cut the residue and incorporate in the soil. Residue was than mix up in the soil by disc plough followed by cultivator and a light irrigation, was given.

The recommended dose of fertilizers for rice (100:60:40 kg N: $\mathrm{P}_{2} \mathrm{O}_{5}: \mathrm{K}_{2} \mathrm{O} \mathrm{ha}^{-1}$ ) was used in the experiment through urea, SSP and MOP. In farmers practice treatment, $103: 57: 45 \mathrm{~kg} \mathrm{~N}$ : $\mathrm{P}_{2} \mathrm{O}_{5}: \mathrm{K}_{2} \mathrm{O}$ ha $^{-1}$ was applied through diaammonium phosphate (DAP), urea and muriate of potash (MOP). The nutrient application was made as per the treatments. The nitrogen through urea was applied in three equal splits i.e. as basal, at tillering and panicle initiation stages. The application $25 \%$ $\mathrm{P}_{2} \mathrm{O}_{5}$ of $\mathrm{RDF}$ or $75 \%$ of $\mathrm{RDF}$ under the treatments of $\mathrm{T}_{3}, \mathrm{~T}_{5}, \mathrm{~T}_{7}$ and $\mathrm{T}_{9} \mathrm{was}$ made through single super phosphate at the time of residue incorporation and at sowing time in basal.

The residue was incorporated 25 days before $\begin{array}{lllll}\text { sowing used with } 25 & \% & \mathrm{P}_{2} \mathrm{O}_{5} & \text { and }\end{array}$ Trichoderma. The remaining amount of phosphorus and full dose of potassium was given as basal. In farmers practice, whole amount of phosphorus was applied through diammonium phosphate and potassium through muriate of potash as basal. While, remaining amount of nitrogen under farmers practice was also applied through urea at tillering and panicle initiation stage. 
The incorporation of residue application of 25 $\% \mathrm{P}_{2} \mathrm{O}_{5}$ and Trichoderma was done as per treatments 25 day before sowing of crops. Trichoderma, $12.5 \mathrm{~kg} \mathrm{ha}^{-1}$ CG Trichome (10 $\%$ Trichoderma culture in varmibase) mixed with FYM in the ratio of 1:10 and broadcasted on the soil mixed residues. The residues was incorporated all the treatments including control.

Observation methods such as plant height was measured in centimeters from the base of each tagged plant to the tip of the longest leaf stretched up to the tip of the panicle at active tillering, panicle initiation stages and from base of the plant to the tip of the panicle at flowering stage. Dry matter accumulation ( $g$ $\mathrm{m}^{-2}$ ) was observed that randomly selected plants were uprooted carefully along with the roots from two places from one meter row length from gross plot. Dry matter accumulations were computed in $\mathrm{m}^{-2}$ for statistical analysis. Root portion was detached and shoot portion of the plant was sun dried followed by drying in hot air oven at $60{ }^{0} \mathrm{C}$ for 48 hours to record constant dry weight.

Dry matter accumulation was expressed in $g$ $\mathrm{m}^{-2}$ and number of tillers meter ${ }^{-1}$ row length from net plot area of each plot were chosen by random sampling and tagged, and were used for recording tiller numbers. However, total number of tillers measure one meter row length, was counted, and expressed as tillers $\mathrm{m}^{-2}$.

Grain and straw yield - After proper sundrying, the produce of the net plot was tied in bundles and weighed to determine the dry matter produce (grain + straw). The clean seeds obtained after threshing and winnowing from each net plot was weighed. The results were expressed on 14 per cent moisture basis. The straw yield was obtained by subtracting weight of the seed yield from the total weight of the bundle and converted to $\mathrm{q} \mathrm{ha}^{-1}$.

\section{Harvest index (\%)}

Harvest index was calculated by adopting the following formula.

Harvest index (\%)

Economic yield

(Grain yield in $\mathrm{q} \mathrm{ha}^{-1}$ )

Biological yield

$\left(\right.$ Grain + Stover yield in $\left.\mathrm{q} \mathrm{ha}^{-1}\right)$

\section{Results and Discussion}

\section{Plant height, Number of tillers and dry matters}

The observation on plant height, Number of tillers and dry matters production at successive growth stages as influenced by nutrient and residue management practices are presented in Table 1.

The application of different treatments significantly increased plant height under treatment $\mathrm{T}_{5}-100 \% \operatorname{RDF}\left[\begin{array}{lll}\left(\mathrm{N}_{100}\right. & \mathrm{P}_{60} & (25 \%\end{array}\right.$ $\mathrm{P}_{2} \mathrm{O}_{5}$ at $\mathrm{RI}$ and $75 \%$ as basal) $\mathrm{K}_{40}$ ] +Trichoderma registered significantly taller plants, which was significantly superior over $\mathrm{T}_{10}$ - control, but was comparable to rest of the treatments during both the years, but it was found statistically similar to treatments $\mathrm{T}_{1}$ - F P $\left(\mathrm{N}_{103} \mathrm{P}_{57.5} \mathrm{~K}_{45}\right), \mathrm{T}_{2}-100 \% \operatorname{RDF}\left(\mathrm{N}_{100} \mathrm{P}_{60} \mathrm{~K}_{40}\right)$, $\mathrm{T}_{3}-100 \%$ RDF $\left[\mathrm{N}_{100} \mathrm{P}_{60}\left(25 \% \mathrm{P}_{2} \mathrm{O}_{5}\right.\right.$ at RI and $75 \%$ as basal) $\left.\mathrm{K}_{40}\right], \mathrm{T}_{4}-100 \%$ RDF $\left(\mathrm{N}_{100} \mathrm{P}_{60} \mathrm{~K}_{40}\right)+$ Trichoderma and $\mathrm{T}_{9}-75 \%$ $\mathrm{RDF}\left[\mathrm{N}_{75} \mathrm{P}_{45}\left(25 \% \mathrm{P}_{2} \mathrm{O}_{5}\right.\right.$ at $\mathrm{RI}$ and $75 \%$ as basal) $\left.\mathrm{K}_{30}\right]+$ Trichoderma during both the years and on mean basis.

The increase in plant height was mainly attributed to the nodes enlargement and application of $\mathrm{T}_{5}-100 \% \mathrm{RDF}\left[\mathrm{N}_{100} \mathrm{P}_{60}(25 \%\right.$ $\mathrm{P}_{2} \mathrm{O}_{5}$ at $\mathrm{RI}$ and $75 \%$ as basal) $\left.\mathrm{K}_{40}\right]$ + Trichoderma released nutrients properly at all the stages according to crop needs and 
utilized by the plants. The application of $25 \%$ $\mathrm{P}_{2} \mathrm{O}_{5}$ of $\mathrm{RDF}$ at the time of residue incorporation supported with Trichoderma fasten the decomposition process and released nutrients rapidly or reduced the losses of nutrients might have been utilized by the crop and produced comparable plant height under aforesaid treatments.

The sufficient nutrients availability during different growth stages of the crop increased cell division, leading to ideal plant stature combined with better range of the plant leaves and increased in plant height. The role of $\mathrm{P}_{2} \mathrm{O}_{5}$ or Trichoderma or their combination for decomposition of residue has been also reported by Pramanik et al., (2004). The Trichoderma species are also able to degrade agricultural and domestic waste relatively quickly without emitting bad odour. Trichoderma has shown greater efficacy and effectiveness in terms of storability and decomposing capabilities. Ilias et al., (2005) and Chowdappa et al., (2013) observed that Trichoderma spp. generates phyto-hormones, which may be key factor in increasing rice plant height. The number of tillers $\mathrm{m}^{-2}$ was significantly affected due to nutrient and residue management practices during both the years The number of tillers increased with the increase in crop age and attained peak at 60 DAS and declined slowly up to harvest.

Among the treatments significantly the highest number of tillers were obtained under treatment $\mathrm{T}_{5^{-}} 100 \%$ RDF $\left[\mathrm{N}_{100} \mathrm{P}_{60}\left(25 \% \mathrm{P}_{2} \mathrm{O}_{5}\right.\right.$ at RI and $75 \%$ as basal) $\mathrm{K}_{40}+$ Trichoderma] during both the years. The comparable number of tillers were also observed under the treatments $\mathrm{T}_{1}$ - F P $\left(\mathrm{N}_{103} \mathrm{P}_{57.5} \mathrm{~K}_{45}\right), \mathrm{T}_{2}-100 \%$ $\operatorname{RDF}\left(\mathrm{N}_{100} \mathrm{P}_{60} \mathrm{~K}_{40}\right), \mathrm{T}_{3}-100 \% \operatorname{RDF}\left[\mathrm{N}_{100} \mathrm{P}_{60}\right.$ (25\% $\mathrm{P}_{2} \mathrm{O}_{5}$ at $\mathrm{RI}$ and $75 \%$ as basal) $\mathrm{K}_{40}$ ], $\mathrm{T}_{4}$ $100 \% \operatorname{RDF}\left(\mathrm{N}_{100} \mathrm{P}_{60} \mathrm{~K}_{40}\right)+$ Trichoderma, and $\mathrm{T}_{9}-75 \%$ RDF $\left[\mathrm{N}_{75} \mathrm{P}_{45}\left(25 \% \mathrm{P}_{2} \mathrm{O}_{5}\right.\right.$ at RI and $75 \%$ as basal) $\left.\mathrm{K}_{30}\right]+$ Trichoderma during both the years. The production of tillers in rice mainly takes place from the nodes appeared on the shoot and sequences as primary, secondary and tertiary tillers. The increase in number of tillers under said treatments was due to application of sufficient nutrients levels. The level of nutrient and residue management practices probably maintained acceptable growth components for residue decomposition which helped to increase more number of tillers at all the stages. The tiller production at higher levels of nutrient application due to better nutrition of the crop has been also reported by Mari et al., (2004).The findings revealed that the dry matter accumulation was significantly affected due to different treatments of nutrient and residue management at all the stages of crop growth during both the years. Among the different treatments, application of $\mathrm{T}_{5}-100 \%$ RDF $\left[\mathrm{N}_{100} \mathrm{P}_{60}\left(25 \% \mathrm{P}_{2} \mathrm{O}_{5}\right.\right.$ at $\mathrm{RI}$ and $75 \%$ as basal) $\left.\mathrm{K}_{40}\right] \quad+$ Trichoderma accumulated significantly the highest dry matter accumulation. The respective value was at harvest stage $1842.9 \mathrm{~g} \mathrm{~m}^{-2}$. This treatment was found significantly superior to those of $\mathrm{T}_{6}$ $75 \% \operatorname{RDF}\left(\mathrm{N}_{75} \mathrm{P}_{45} \mathrm{~K}_{30}\right), \mathrm{T}_{7}-75 \% \operatorname{RDF}\left[\mathrm{N}_{75} \mathrm{P}_{45}\right.$ $\left(25 \% \mathrm{P}_{2} \mathrm{O}_{5}\right.$ at $\mathrm{RI}$ and $75 \%$ as basal) $\left.\mathrm{K}_{30}\right], \mathrm{T}_{8}$ $75 \% \operatorname{RDF}\left[\begin{array}{lll}\mathrm{N}_{75} & \mathrm{P}_{45} & \mathrm{~K}_{30}\end{array}\right]+$ Trichoderma and $\mathrm{T}_{10}$ - control at all the stages. The remaining treatments produced comparable dry matter to that of $\mathrm{T}_{5}-100 \% \mathrm{RDF}\left[\mathrm{N}_{100} \mathrm{P}_{60}\left(25 \% \mathrm{P}_{2} \mathrm{O}_{5}\right.\right.$ at $\mathrm{RI}$ and $75 \%$ as basal) $\left.\mathrm{K}_{40}\right]+$ Trichoderma at all the stages during both the years. Nitrogen is an important nutrient responsible for growth and development of plant. Phosphorus is an important part of ATP, the molecule that provides energy to the plant for vigorous techniques such as photosynthesis, protein synthesis, nutrient translocation, nutrient uptake and respiration. Phosphorus helps root development, tillering, and blooming because, increasing of metabolic activities. The potassium helps in protein and starch synthesis in plant. Due to this, plant height, number of leaves, number of tillers, leaf area and leaf area index at early stage and in addition of 
these, panicle weight at later stages of crop growth. It was interesting to note that when $75 \% \mathrm{RDF}$ was given under $\mathrm{T}_{9}-75 \% \mathrm{RDF}$

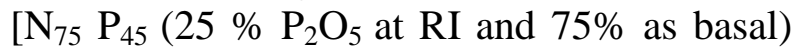
$\mathrm{K}_{30}$ ]+Trichoderma also produced similar dry matter at all the stages. This indicate that addition 25\% $\mathrm{P}_{2} \mathrm{O}_{5}$ of $\mathrm{RDF}$ and Trichoderma 25 days before sowing for decomposition of residue also improved soil physical condition, enhanced availability of nutrients and growth parameters (height, tillers and leaves) and finally dry matter production. Similar finding have been reported by Panhwar et al., (2011) and Meena (2014).

\section{Grain yield, straw yield and harvest index}

The grain and straw yields and harvest index of rice was influenced by nutrient and residues management during both the years and on mean basis (Table 2). Among the different treatments of nutrient and residue management practices, significantly the highest grain yield was obtained under treatment of $\mathrm{T}_{5}-100 \% \mathrm{RDF}\left[\mathrm{N}_{100} \mathrm{P}_{60}(25 \%\right.$ $\mathrm{P}_{2} \mathrm{O}_{5}$ at $\mathrm{RI}$ and $75 \%$ as basal) $\left.\mathrm{K}_{40}\right]$ +Trichoderma during both the years (54.67 and $\left.58.75 \mathrm{q} \mathrm{ha}^{-1}\right)$. This treatment was significantly superior to $\mathrm{T}_{6}-75 \% \mathrm{RDF}\left(\mathrm{N}_{75}\right.$ $\left.\mathrm{P}_{45} \mathrm{~K}_{30}\right), \mathrm{T}_{7-} 75 \%$ RDF $\left[\mathrm{N}_{75} \mathrm{P}_{45}\left(25 \% \mathrm{P}_{2} \mathrm{O}_{5}\right.\right.$ at $\mathrm{RI}$ and $75 \%$ as basal) $\mathrm{K}_{30}$ ], $\mathrm{T}_{8-}-75 \% \mathrm{RDF}\left[\mathrm{N}_{75}\right.$ $\left.\mathrm{P}_{45} \mathrm{~K}_{30}\right]+$ Trichoderma and $\mathrm{T}_{10}$ - control (no fertilizer). The remaining treatments i.e. $\mathrm{T}_{1}-\mathrm{F}$ $\mathrm{P}\left(\mathrm{N}_{103} \mathrm{P}_{57.5} \mathrm{~K}_{45}\right), \mathrm{T}_{2}-100 \% \operatorname{RDF}\left(\mathrm{N}_{100} \mathrm{P}_{60}\right.$ $\left.\mathrm{K}_{40}\right), \mathrm{T}_{3}-100 \%$ RDF $\left[\mathrm{N}_{100} \mathrm{P}_{60}\left(25 \% \mathrm{P}_{2} \mathrm{O}_{5}\right.\right.$ at $\mathrm{RI}$ and $75 \%$ as basal) $\mathrm{K}_{40}$ ] and $\mathrm{T}_{4}-100 \% \mathrm{RDF}$ $\left[\mathrm{N}_{100} \mathrm{P}_{60}\left(25 \% \mathrm{P}_{2} \mathrm{O}_{5}\right.\right.$ at $\mathrm{RI}$ and $75 \%$ as basal $)$ $\mathrm{K}_{40}$ ] were found to be at par to that of $\mathrm{T}_{5}$ $100 \%$ RDF $\left[\begin{array}{lllll}\mathrm{N}_{100} & \mathrm{P}_{60} & (25 \% & \mathrm{P}_{2} \mathrm{O}_{5} & \text { at } \mathrm{RI}\end{array}\right.$ $75 \%$ as basal) $\left.\mathrm{K}_{40}\right]+$ Trichoderma. While, treatment $\mathrm{T}_{9}-75 \%$ RDF $\left[\mathrm{N}_{75} \mathrm{P}_{45}\left(25 \% \mathrm{P}_{2} \mathrm{O}_{5}\right.\right.$ at $\mathrm{RI}$ and $75 \%$ as basal) $\mathrm{K}_{30}$ ] + Trichoderma was also at par during 2016-17. Almost similar trend was noticed for straw yield during both the years (79.10 and $\left.81.06 \mathrm{q} \mathrm{ha}^{-1}\right)$.
But, treatment $\mathrm{T}_{9}-75 \%$ RDF $\left[\mathrm{N}_{75} \mathrm{P}_{45}(25 \%\right.$ $\mathrm{P}_{2} \mathrm{O}_{5}$ at $\mathrm{RI}$ and $75 \%$ as basal) $\left.\mathrm{K}_{30}\right]+$

Trichoderma was also at par during 2017-18. The application of $25 \% \mathrm{P}_{2} \mathrm{O}_{5}$ of $\mathrm{RDF}$ along with Trichoderma used for fasten the decomposition of maize stover, favored crop growth and development and finally enhanced the yield components and grain and straw yields of rice under different treatments of rice. The study of Hua et al., (2013) also revealed that straw incorporation along with $\mathrm{N}, \mathrm{P}$ and $\mathrm{K}$ fertilization into soils significantly increased grain yield of early rice due to improved soil fertility. The similar findings have been also reported by Marciano et al., (1997) and Upadhyay et al., (2003). The application of Trichoderma increased residue decomposition and several rice physiological processes, which includes net photosynthetic rate, transpiration and internal $\mathrm{CO}_{2}$ concentration, enhance crop growth components including plant height, number of leaves, and number of tillers and finally grain and straw yields of rice (Deshmukh et al., 2001 and Pandey and Agarwal, 2003)

The application of $\mathrm{T}_{5}-100 \% \mathrm{RDF}\left[\mathrm{N}_{100} \mathrm{P}_{60}\right.$ (25 \% $\mathrm{P}_{2} \mathrm{O}_{5}$ at $\mathrm{RI}$ and $75 \%$ as basal) $\mathrm{K}_{40}$ ] + Trichoderma gave significantly the highest nitrogen and potassium uptake by grain and straw on the basis of mean of both the years. This treatment was found to be statistically similar to those of $\mathrm{T}_{1}-\mathrm{FP}\left(\mathrm{N}_{103} \mathrm{P}_{57.5} \mathrm{~K}_{45}\right), \mathrm{T}_{2}$ $100 \%$ RDF $\left[\begin{array}{llll}\mathrm{N}_{100} & \mathrm{P}_{60} & \mathrm{~K}_{40}\end{array}\right], \mathrm{T}_{3}-100 \% \mathrm{RDF}$ $\left[\mathrm{N}_{100} \mathrm{P}_{60}\left(25 \% \mathrm{P}_{2} \mathrm{O}_{5}\right.\right.$ at $\mathrm{RI}$ and $75 \%$ as basal $)$ $\left.\mathrm{K}_{40}\right], \mathrm{T}_{4}-100 \%$ RDF $\left[\mathrm{N}_{100} \mathrm{P}_{60}\left(25 \% \mathrm{P}_{2} \mathrm{O}_{5}\right.\right.$ at $\mathrm{RI}$ and $75 \%$ as basal) $\mathrm{K}_{40}$ ] and $\mathrm{T}_{9}-75 \% \mathrm{RDF}$ $\left[\begin{array}{lllll}\mathrm{N}_{75} & \mathrm{P}_{45} & (25 & \% & \mathrm{P}_{2} \mathrm{O}_{5}\end{array}\right.$ at $\mathrm{RI}$ and $75 \%$ as basal $)$ $\mathrm{K}_{30}$ ] + Trichoderma during both the years and on mean basis. The remaining treatments were produced significantly inferior uptake by grains and straw than that of $\mathrm{T}_{5}-100 \% \mathrm{RDF}$ $\left[\mathrm{N}_{100} \mathrm{P}_{60}\left(25 \% \mathrm{P}_{2} \mathrm{O}_{5}\right.\right.$ at $\mathrm{RI}$ and $75 \%$ as basal $)$ $\left.\mathrm{K}_{40}\right]+$ Trichoderma . 
Table.1 Plant height, Number of tillers and dry matter of rice at different time intervals as influenced by nutrient and residue management practices in rice - maize cropping system

\begin{tabular}{|c|c|c|c|c|c|c|}
\hline \multirow[t]{2}{*}{ Treatment } & \multicolumn{2}{|c|}{$\begin{array}{l}\text { Plant height } \\
\quad(\mathrm{cm})\end{array}$} & \multicolumn{2}{|c|}{$\begin{array}{l}\text { Tillers } \\
\text { (No.) }\end{array}$} & \multicolumn{2}{|c|}{$\begin{array}{l}\text { Dry matters } \\
\left(\mathrm{g} \mathrm{m}^{2}\right)\end{array}$} \\
\hline & 2016 & 2017 & 2016 & 2017 & 2016 & 2017 \\
\hline$T_{1}-F P\left(N_{103} P_{57.5} K_{45}\right)$ & 114 & 119 & 311 & 320 & 1477 & 1811 \\
\hline$T_{2-} 100 \%$ RDF $\left(N_{100} P_{60} K_{40}\right)$ & 116 & 122 & 306 & 317 & 1469 & 1728 \\
\hline 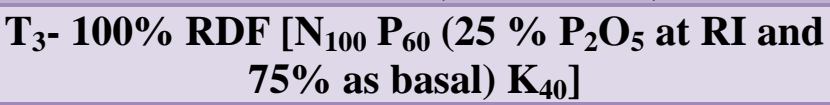 & 122 & 127 & 309 & 322 & 1543 & 1708 \\
\hline $\mathrm{T}_{4}-100 \%$ RDF $\left(\mathrm{N}_{100} \mathrm{P}_{60} \mathrm{~K}_{40}\right)+$ Trichoderma & 123 & 129 & 309 & 326 & 1661 & 1791 \\
\hline $\begin{array}{c}T_{5^{-}} 100 \% \text { RDF }\left[\mathrm{N}_{100} \mathrm{P}_{60}\left(25 \% \mathrm{P}_{2} \mathrm{O}_{5} \text { at } \mathrm{RI} \text { and }\right.\right. \\
\left.75 \% \text { as basal) } \mathrm{K}_{40}\right]+ \text { Trichoderma }\end{array}$ & 125 & 130 & 318 & 330 & 1810 & 1876 \\
\hline$T_{6}-75 \%$ RDF $\left(N_{75} P_{45} K_{30}\right)$ & 97.6 & 97.7 & 246 & 290 & 1110 & 1209 \\
\hline $\begin{array}{c}\mathrm{T}_{7-}-75 \% \mathrm{RDF}\left[\mathrm{N}_{75} \mathbf{P}_{45}\left(25 \% \mathbf{P}_{2} \mathrm{O}_{5} \text { at } \mathrm{RI} \text { and }\right.\right. \\
\left.75 \% \text { as basal) } \mathrm{K}_{30}\right]\end{array}$ & 98.8 & 105 & 287 & 292 & 1191 & 1288 \\
\hline $\mathrm{T}_{8^{-}} \mathbf{7 5} \% \mathrm{RDF}\left(\mathrm{N}_{75} \mathrm{P}_{45} \mathrm{~K}_{30}\right)+$ Trichoderma & 105 & 114 & 292 & 298 & 1326 & 1395 \\
\hline $\begin{array}{c}\mathrm{T}_{9-75 \%} \mathrm{RDF}\left[\mathrm{N}_{75} \mathrm{P}_{45}\left(25 \% \mathrm{P}_{2} \mathrm{O}_{5} \text { at } \mathrm{RI} \text { and }\right.\right. \\
\left.75 \% \text { as basal) } \mathrm{K}_{30}\right]+ \text { Trichoderma }\end{array}$ & 113 & 115 & 307 & 318 & 1454 & 1591 \\
\hline $\mathbf{T}_{10^{-}}$Control (no fertilizer) & 86.8 & 89 & 191 & 198 & 970 & 1103 \\
\hline SEm \pm & 4.6 & 5 & 8 & 7 & 113.7 & 97.2 \\
\hline $\mathrm{CD}(\mathrm{P}=\mathbf{0 . 0 5})$ & 13.7 & 14.9 & 25 & 20 & 358.3 & 288.7 \\
\hline
\end{tabular}

Table.2 Grain yield, straw yield, and harvest index of rice as influenced by nutrient and residue management practices in rice - maize cropping system

\begin{tabular}{|c|c|c|c|c|c|c|}
\hline \multirow[t]{2}{*}{ Treatment } & \multicolumn{2}{|c|}{$\begin{array}{c}\text { Grain yield } \\
\left(\mathbf{q} \mathbf{h a}^{-1}\right)\end{array}$} & \multicolumn{2}{|c|}{$\begin{array}{c}\text { Straw yield } \\
\left(\mathbf{q} \mathbf{h a}^{-1}\right)\end{array}$} & \multicolumn{2}{|c|}{$\begin{array}{c}\text { Harvest } \\
\text { index }(\%)\end{array}$} \\
\hline & 2016 & 2017 & 2016 & 2017 & 2016 & 2017 \\
\hline$T_{1}-F P\left(N_{103} P_{57.5} K_{45}\right)$ & 50.6 & 53.2 & 75.4 & 77.3 & 40.15 & 40.8 \\
\hline$T_{2 .} 100 \% \operatorname{RDF}\left(N_{100} P_{60} K_{40}\right)$ & 51.5 & 54.7 & 73.2 & 76.9 & 41.3 & 41.96 \\
\hline $\begin{array}{c}\mathrm{T}_{3^{-}} 100 \% \text { RDF [ }\left[\mathrm{N}_{100} \mathrm{P}_{60}\left(25 \% \mathrm{P}_{2} \mathrm{O}_{5} \text { at } \mathrm{RI} \text { and } 75 \% \text { as }\right.\right. \\
\left.\text { basal) } \mathrm{K}_{40}\right]\end{array}$ & 53 & 55.9 & 76.9 & 78.5 & 40.81 & 41.58 \\
\hline$T_{4}-100 \%$ RDF $\left(N_{100} P_{60} K_{40}\right)+$ Trichoderma & 53.6 & 57 & 78.3 & 80.5 & 40.61 & 41.74 \\
\hline $\begin{array}{c}\mathrm{T}_{5^{-}} 100 \% \mathrm{RDF}\left[\mathrm{N}_{100} \mathrm{P}_{60}\left(25 \% \mathrm{P}_{2} \mathrm{O}_{5} \text { at } \mathrm{RI} \text { and } 75 \% \text { as }\right.\right. \\
\left.\text { basal) } \mathrm{K}_{40}\right]+ \text { Trichoderma }\end{array}$ & 54.7 & 58.8 & 79.1 & 81.1 & 41.16 & 42.44 \\
\hline$T_{6^{-}} 75 \% \operatorname{RDF}\left(\mathrm{N}_{75} \mathbf{P}_{45} K_{30}\right)$ & 45.5 & 47.2 & 68.8 & 69.4 & 39.81 & 40.47 \\
\hline $\begin{array}{c}\mathrm{T}_{7^{-}} \mathbf{7 5} \% \mathrm{RDF}\left[\mathrm{N}_{75} \mathbf{P}_{45}\left(25 \% \mathbf{P}_{2} \mathrm{O}_{5} \text { at } \mathrm{RI} \text { and } 75 \% \text { as }\right.\right. \\
\left.\text { basal) } \mathbf{K}_{30}\right]\end{array}$ & 46.2 & 49.3 & 69.7 & 70.1 & 39.85 & 41.29 \\
\hline $\mathrm{T}_{8^{-}} \mathbf{7 5 \%} \mathrm{RDF}\left(\mathrm{N}_{75} \mathbf{P}_{45} \mathrm{~K}_{30}\right)+$ Trichoderma & 48.1 & 51.1 & 70.9 & 73.4 & 40.42 & 41.02 \\
\hline $\begin{array}{c}\mathrm{T}_{9}-75 \% \mathrm{RDF}\left[\mathrm{N}_{75} \mathbf{P}_{45}\left(25 \% \mathrm{P}_{2} \mathrm{O}_{5} \text { at } \mathrm{RI} \text { and } 75 \% \text { as }\right.\right. \\
\left.\text { basal) } \mathrm{K}_{30}\right]+ \text { Trichoderma }\end{array}$ & 49.9 & 52.6 & 72.7 & 75.9 & 40.7 & 40.98 \\
\hline$T_{10^{-}}$Control (no fertilizer) & 27.9 & 29 & 45.6 & 47.4 & 37.95 & 36.24 \\
\hline $\operatorname{SEm} \pm$ & 1.66 & 1.74 & 1.6 & 2.24 & 1.19 & 0.95 \\
\hline $\mathrm{CD}(\mathrm{P}=\mathbf{0 . 0 5})$ & 4.85 & 5.16 & 4.74 & 6.65 & NS & 2.83 \\
\hline
\end{tabular}


The comparison of treatments revealed that application of $\mathrm{T}_{5}-100 \%$ RDF $\left[\mathrm{N}_{100} \mathrm{P}_{60}(25 \%\right.$ $\mathrm{P}_{2} \mathrm{O}_{5}$ at $\mathrm{RI}$ and $75 \%$ as basal) $\left.\mathrm{K}_{40}\right]$ +Trichoderma produced significantly the highest uptake of phosphorus in grain and straw and was found comparable with the treatments of $\mathrm{T}_{3}-100 \% \mathrm{RDF}\left[\mathrm{N}_{100} \mathrm{P}_{60}(25 \%\right.$ $\mathrm{P}_{2} \mathrm{O}_{5}$ at $\mathrm{RI}$ and $75 \%$ as basal) $\left.\mathrm{K}_{40}\right]$ and $\mathrm{T}_{4}-$ $100 \%$ RDF $\left[\mathrm{N}_{100} \mathrm{P}_{60}\left(25 \% \mathrm{P}_{2} \mathrm{O}_{5}\right.\right.$ at $\mathrm{RI}$ and $75 \%$ as basal) $\left.\mathrm{K}_{40}\right], \mathrm{T}_{8^{-}}-75 \%$ RDF $\left[\mathrm{N}_{75} \mathrm{P}_{45}\right.$ $\left.\mathrm{K}_{30}\right]+$ Trichoderma during both the years and on mean basis. The remaining all the treatments were found to be inferior to that of $\mathrm{T}_{5}-100 \% \operatorname{RDF}\left[\mathrm{N}_{100} \mathrm{P}_{60}\left(25 \% \mathrm{P}_{2} \mathrm{O}_{5}\right.\right.$ at $\mathrm{RI}$ and $75 \%$ as basal) $\mathrm{K}_{40}$ ] + Trichoderma during both the years and on mean basis. The lowest uptake of $\mathrm{P}$ in grain $(0.18 \%)$ and straw $(0.10 \%)$ was observed under $\mathrm{T}_{10^{-}}$control.

The increased $\mathrm{N}$ availability due to application of different nutrient levels and management of practices adapted for residue decomposition i.e. $25 \%$ of total $\mathrm{P}$ or Trichoderma or its combination applied at the time of residue incorporation under above treatments enhanced the availability and utilization of $\mathrm{N}$ for metabolic activities in plant, increased $\mathrm{N}$ concentration in grains and straw. The uptake is a function of concentration and dry matter production, however, increased concentration and yields of grain and straw enhanced the uptake of nitrogen. The findings have been also supported by Maskina et al., (2004).The application of different levels of nutrients and management practices adapted for residue decomposition i.e. application of $25 \%$ of total $\mathrm{P}$ or Trichoderma at the time of residue incorporation enhanced the availability and absorption of $\mathrm{P}$ and increased concentration in grains and straw. The increased concentration and yields of grains and straw finally enhanced the uptake of phosphorus. The similar results have been also reported by Singh et al., (2005), Devi et al., (2012) and Jhansi et al., (2013). The high uptake of potassium in grain and rice straw was mainly due to increased availability and absorption under above treatments. The application of nutrients and Trichoderma might improve the structure of the soil, provide a better environment for root growth, thereby creating a more absorption surface for the uptake of potassium (Singh et al., 2005)

For rice crop, application100:60 (25\% at time of residue incorporation and $75 \%$ as basal):40, $\mathrm{N}: \mathrm{P}_{2} 0_{5}: \mathrm{K}_{2} \mathrm{O} \mathrm{kg} \mathrm{ha}{ }^{-1}+$ Trichoderma $\left(\mathrm{T}_{5}\right)$ proved superior in terms of growth and yield attributes such as plant height, number of tillers and dry matter production, grain and stover yield. Further, the other comparable treatments were $\mathrm{T}_{1}$ - F P $\left(\mathrm{N}_{103} \mathrm{P}_{57.5} \mathrm{~K}_{45}\right), \mathrm{T}_{2}$ $100 \%$ RDF $\left[\begin{array}{llll}\mathrm{N}_{100} & \mathrm{P}_{60} & \mathrm{~K}_{40}\end{array}\right], \mathrm{T}_{3}-100 \% \mathrm{RDF}$ $\left[\mathrm{N}_{100} \mathrm{P}_{60}\left(25 \% \mathrm{P}_{2} \mathrm{O}_{5}\right.\right.$ at $\mathrm{RI}$ and $75 \%$ as basal $)$ $\mathrm{K}_{40}$ ], $\mathrm{T}_{4}-100 \%$ RDF $\left[\mathrm{N}_{100} \mathrm{P}_{60}\left(25 \% \mathrm{P}_{2} \mathrm{O}_{5}\right.\right.$ at $\mathrm{RI}$ and $75 \%$ as basal) $\mathrm{K}_{40}$ ] and $\mathrm{T}_{9}-75 \% \mathrm{RDF}$ $\left[\mathrm{N}_{75} \mathrm{P}_{45}\left(25 \% \mathrm{P}_{2} \mathrm{O}_{5}\right.\right.$ at $\mathrm{RI}$ and $75 \%$ as basal $)$ $\left.\mathrm{K}_{30}\right]+$ Trichoderma .

\section{Acknowledgement}

I am extremely grateful to the Scientist and Professor, Department of Farm Machinery and Power Engineering, Faculty of Agriculture Engineering, Indira Gandhi Krishi Vishwa vidyalaya Raipur Chhattisgarh for his support and availability of machineries facilitation for carrying out the research work successfully.

\section{References}

Anonymous, 2015. Annual report Department of Agriculture cooperation ministry of Agriculture, Government of India, Krishi Bhavan New Delhi, pp. 2.

Anonymous, 2016a. Digdarsika, Indira Gandhi Krishi Visvawa vidyalaya, Raipur.

Anonymous, 2016b. World Agricultural production 2016. Foreign Agriculture Service, United States Department of Agriculture Circular series, 8-16. 
Balasubramanian P., Palaniappan S. P. and Francis H. J. 1991 Effect of green manuring and inorganic $\mathrm{N}$ and $\mathrm{K}$ fertilization on nutrient uptake and yield of lowland rice. Indian Journal of Agronomy, 36(2): 293-295.

Chowdappa P, Kumar SPM, Lakshmi MJ, Upreti KK. 2013. Growth stimulation and induction of systemic resistance in tomato against early and late blight by Bacillus subtilis or Trichoderma harzianum Biological Control, 2013, 4:109-117.

Deshmukh, M.R., Shukla, R.K., Rajput, R.P., Paredkar, V.K. and Tiwari, K.L. 2001.Response of early rice varieties to level of fertility. Indian Journal of Agronomy, 33 (1): 10-13.

Devi, M.G., Reddy, S.T., Sumathi V., Pratima, T. and John, K. 2012.Nitrogen management to improve the nutrient uptake, yield and quality parameters of scented rice under aerobic culture. International Journal of Applied Biology and Pharmaceutical Technology, 3(1): 340-344.

Hua, Z.Y., Fu, W.J., Hua, P.X., Hua, S.Q. and Feng, Z.D. 2013. Effects of straw incorporation method on double cropping rice yield and the top-three leaf characteristics. Journal of Ecology Agriculture, 21(12): 1459-1466.

Ilias, G.N.M., Rahman, M.A. and Molla, A.H., 2005. Composting of municipal garbage by using Trichoderma a new approach in contextof Bangladesh. Journal Genetics Biotechnology, 6(1\&2): 75- 78 .

Jhansi, L.B.K., Ramana, M.K.V. and Naidu, V.M. 2013. Effect of graded levels and time of nitrogen application on nutrient uptake, yield and economics of semidry rice Oryza sativa L. Journal Research Agriculture., 41(2): 21-25.

Krishna, G., Mandal, Arun K., Misra, Kuntal M., Hati, Kali K., Bandyopadhyay,
PrabirK. and Manoranjan Mohanty 2004. Rice residue- management options and effects on soil properties and crop productivity. Science and Technology Food, Agriculture\& Environment. 2(1): 224-231.

Marciano, V.P., Mandac, A.M. and Flinn, J.C. 1997.Rice straw management in the Philippines. $14^{\text {th }}$ Annual Scientific Meeting of the Crop Science Society of the Philippines, IRRI, Los Banos, Laguna.2-4.

Mary B, Recous S, Darwis D, Robin D., 2004. Interactions between decomposition of plant residues and nitrogen cycling in soil. Plant and Soil 181, 71-82.

Maskina, M.S., Singh, B., Singh, Y and Meelu, D.P. 2004. Integrated nitrogen management with green manures in rice-wheat cropping system. Oryza. 26(4) : 358-362.

Meena, B.L. and Singh, R.K. 2014. Response of wheat (Triticum aestivum) to rice (Oryza sativa L.) residue and weed management practices. Indian Journal of Agronomy, 58(4): 521-524.

Pandey, R., and Agrawal, M.M. 2003. Influence of fertility levels, varieties and time on rice (Oryza sativa). Indian Journal of Agronomy, 36(4): 459-463.

Panhawar, C.P., Gurmel. K., and Sauki, R.K. 2011.Straw as a source of nutrients for wet land rice and Organic Matter in Rice. International Rice Research Institute, Los Banos, Philippines, pp. 117-135.

Pramanik M Y A, Sarkar M A R, Islam M A and Samad M A 2004. Effect of green manures and different levels of nitrogen on the yield and yield components of Rice.Journal of Agronomy 3(2): 122- 125.

Prasad, R. and Power, J.F., 1991. Crop residue management. Advance Soil Science, 15: 205-239. 
Singh, L. N., Singh, R. K. K., Singh, A. H. and Chhangte, Z., 2005. Efficacy of urea in integration with Aolla and vermicompost in rainfed rice (Oryza sativa) production and their residual effect on soil properties. International Journal of Agricultural Sciences,
75(1): 44-45.

Upadhyay, S. K., Bajpai, R. K. and Tripathi, R. S. 2003. Integrated nutrient management in rice-wheat cropping system in Chhattisgarh. Journal Agriculture Issues, 8(1\&2): 69-74.

\section{How to cite this article:}

Mukesh Kumar Pandey, Narendra Pandey, Rajendra Lakpale and Ajay Verma. 2019. Effect of Nutrient and Residue Management Practices on Growth and Yield of Rice in Rice - Maize Cropping System. Int.J.Curr.Microbiol.App.Sci. 8(12): 461-469. doi: https://doi.org/10.20546/ijcmas.2019.812.061 